\title{
Euclidean Genetic Distances of Four Manila Clam (Ruditapes philippinarum) Populations analyzed by PCR Research
}

\author{
${ }^{\dagger}$ Jong-Man Yoon \\ Department of Aquatic Life Medicine, College of Ocean Science and Technology, Kunsan National University, \\ Gunsan 54150, Korea
}

\begin{abstract}
The PCR analysis was performed on DNA samples extracted from a total of 20 individuals using six oligonucleotides primers. The author accomplished clustering analyses to reveal the Euclidean genetic distances among four clam populations from Gochang, Seocheon, Taean and Anmyeon of the Korean peninsula. The oligonucleotides primer OPA-08 generated 5 unique loci to each population, approximately $550 \mathrm{bp}$ and $600 \mathrm{bp}$, respectively, in the MCS population. Especially, the primer OPA-20 generated 15 unique loci to each population, which were identifying each population, approximately 400 bp, $750 \mathrm{bp}$ and $800 \mathrm{bp}$, in the MCT population. Individuals from MCG clam population $(0.637 \pm 0.227)$ exhibited higher bandsharing values than did individuals from MCG clam population $(0.402 \pm 0.115)(P<0.05)$. The dendrogram obtained by the six oligonucleotides primers indicates four genetic clusters: cluster 1 (MCG 01, 02, 04 and 05), cluster 2 (MCS 06, 07, 08, 09 and 10), cluster 3 (MCT 11, 12, 13, 14 and 15) and cluster 4 (MCA 16, 17, 18, 19, 20 and MCG 03). Among the twenty clam individuals, the shortest genetic distance that displayed significant molecular differences was between individuals 14 and 15 from the MCT population (genetic distance $=0.094$ ), while the longest genetic distance among the twenty individuals that displayed significant molecular differences was between individuals MCG no. 01 and MCG no. 02 (genetic distance $=0.687$ ). Comparatively, individuals of MCS clam population were fairly closely related to that of MCT clam population, as shown in the hierarchical dendrogram of Euclidean genetic distances.
\end{abstract}

Key words : Euclidean genetic distance, Hierarchical dendrogram, Manila clam, Ruditapes philippinarum

\section{INTRODUCTION}

Manila clam (R. philippinarum) is, environmentally warmwater bivalve species, belonging to family Veneridae, widely distributed on the coast of the Yellow Sea in the Korean Peninsula, as well as in several areas in China under the natural ecosystem. The clam is also indigenous to some parts of the sandy regions consisting of coarse sand and slime from 5 to $10 \mathrm{~m}$ in depth. Clams are the most popular marine products in Korea because of their taste and nutritional value, and Koreans consume them in large quantities. The coarse surface of this shellfish species is light gray and clean white, and the inside is white under the natural conditions. Inner feet are short, triangular, and white-gray. Mostly, there are marked differences of the shell weight, size, color and shape in $R$. philippinarum in line with the environmental conditions of habitat such as feed, water temperature and water depth. Nevertheless, these kinds of Korean bivalve, which are recognized important morphologically (Kwon, 1999; Kang, 2000;

\footnotetext{
Manuscript received September 13, 2017, Received in revised form September 16, 2017, Accepted September 18, 2017

$\dagger$ Corresponding Author : Jong-Man Yoon, Department of Aquatic Life Medicine, College of Ocean Science and Technology, Kunsan National University, Gunsan 54150, Korea. Tel: +82-64-469-1887, E-mail: jmyoon@kunsan.ac.kr

This is an Open Access article distributed under the terms of the Creative Commons Attribution Non-Commercial License (http:// creativecommons.org/licenses/by-nc/3.0) which permits unrestricted non-commercial use, distribution, and reproduction in any medium, provided the original work is properly cited.
} 
Choi, 2000), environmentally (Cho, 2001; Shin, 2000), physiologically (Robert, 1993), reproductively (Lee, 1996), as well as histologically (Lee \& Chung, 2008), are not genetically and/or molecular-biologically studied like other crustaceans. Basically, there are marked differences of the size, color and shape in R. philippinarum according to the ecological conditions of habitat such as nourish and hard period. There is a need to understand the genetic traits and composition of this clam population in order to evaluate precisely the patent genetic consequence. Particularly, the polymorphic and/or specific markers specific to the species, the genus or the geographical populations have been applied for the of individuals and species, hybrid parentage and for the screening of DNA markers (Partis \& Wells, 1996; Muchmore et al., 1998; Tassanakajon et al., 1998; McCormack et al., 2000; Park et al., 2005; Song \& Yoon, 2013). So far, specific fragments generated by this PCR method using arbitrary primers had virtuous merits for detecting DNA similarity and diversity between life creatures (McCormack et al., 2000). The polymorphisms are determined by the banding patterns of amplified products at the specific positions by primers (Tassanakajon et al., 1998; Yoon \& Kim, 2004). The author accomplished clustering analyses to reveal the Euclidean genetic distances among four clam populations from Gochang, Seocheon, Taean and Anmyeon of the Korean peninsula.

\section{MATERIALS AND METHODS}

Adductor muscle tissues were collected separately from four $R$. philippinarum populations of Gochang (Manila clam from Gochang; MCG), Seocheon (Manila clam from Seocheon; MCS), Taean (Manila clam from Taean; MCT) and Anmyeon (Manila clam from Anmyeon; MCA) of the Korean peninsula, respectively. PCR analysis was performed on DNA samples extracted from a total of 20 individuals using six oligonucleotides primers. DNA extraction should be carried out according to the separation and extraction methods (Song \&Yoon, 2013). After several washings, lysis buffer I $\left(155 \mathrm{mM} \mathrm{NH}_{4} \mathrm{Cl} ; 10 \mathrm{mM} \mathrm{KHCO}_{3}\right.$; $1 \mathrm{mM}$ EDTA) was added to the samples, and the mixture tubes were gently inverted. Ice-cold $70 \%$ ethanol was added, and then the samples were centrifuged at $19,621 \mathrm{~g}$ for 5 minutes to extract the DNA from the lysates. The concentration of the extracted genomic DNA was measured with the absorbance ratio at $260 \mathrm{~nm}$ by a spectrophotometer (Beckman Coulter, Buckinghamshire, UK). The DNA pellets were then incubation-dried for more than 10 hours, maintained at $-40{ }^{\circ} \mathrm{C}$ until analysis and then dissolved in the distilled water. Amplification products were separated by electrophoresis in $1.4 \%$ agarose gels with TBE, using DNA ladder (Operon Technologies, Alameda, CA, USA) as DNA molecular weight marker and detected by staining with ethidium bromide. The author used the oligonucleotides primers to certify the genetic distances of R. philippinarum individuals. Six oligonucleotides primers (Operon Technologies, Alameda, CA, USA), OPA-08 (5'- GTGACGTAGG-3'), OPA-09 (5'-GGGTAA CGCC3'), OPA-11 (5'-CAATCGCCGT-3'), OPA-16 (5'AGCCAG CGA A-3'), OPA-18 (5'-AGGTGACCGT-3'), and OPA-20 (5'-GTTGCGATCC-3') were shown to generate the unique shared loci to each population and shared loci by the four $R$. philippinarum populations which could be clearly scored. Thus, the author used the primers to study the genetic variations and DNA polymorphisms of the Manila clam. PCR was performed using Programmable DNA Thermal Cycler (MJ Research Inc., Waltham, MA, USA) repeatedly. Six oligonucleotides primers were shown to generate the unique shared loci to each population and shared loci by the four populations which could be clearly counted. The electrophoresed agarose gels were illuminated by ultraviolet rays, and photographed using a photoman direct copy system (PECA Products, Beloit, WI, USA). Similarity matrix including bandsharing values (BS) between different individuals in the four Manila clam populations was generated according formula of Jeffreys \& 
Morton (1987) and Yoke-Kqueen \& Radu (2006). A hierarchical clustering tree was assembled using similarity matrices to yield a dendrogram, which was assisted by the Systat version 10 (SPSS Inc., Chicago, IL, USA).

\section{RESULTS AND DISCUSSION}

The number of unique shared loci to each Manila clam population and number of shared loci by the four clam population generated by PCR investigation using six oligonucleotides primers in the four Manila clam populations, respectively, as summarized in Table 1. The oligonucleotides primer OPA- 08 generated 5 unique loci to each population, approximately $550 \mathrm{bp}$ and $600 \mathrm{bp}$, respectively, in the Seocheon population. Especially, the primer OPA-20 generated 15 unique loci to each population, which were identifying each population, approximately 400 bp, 750 bp and $800 \mathrm{bp}$, in the MCT population. The primer OPA-20 generated 10 unique loci to each population, which were determining each population, approximately $400 \mathrm{bp}$ and
$450 \mathrm{bp}$, in the MCA population. Interestingly, every primer had not distinguished the shared loci by the four populations, major and/or minor fragments of sizes, which were identical in almost all of the samples. Several investigators researched the sizes of DNA fragments in the PCR frameworks of Eastern Pacific abalone (genus Haliotis) (Muchmore et al., 1998), black tiger shrimp (Penaeus monodon) (Tassanakajon et al., 1998), the brittle star (Amphiura filiformis) (McCormack et al., 2000), catfish (S. asotus) and bullhead (P. fulvidraco) populations (Yoon \& Kim, 2004) and Pollicipes mitella population (Song \& Yoon, 2013). Multiple comparisons of average bandsharing values among Manila clam populations from four sections were generated according to the bandsharing values and similarity matrix (Table 2). Ultimately, individuals from MCS clam population $(0.637 \pm 0.227)$ exhibited higher bandsharing values than did individuals from MCG clam population $(0.402 \pm 0.115)(P<0.05)$. As shown in Fig.1, the dendrogram obtained by the six oligonucleotides primers indicates four genetic clusters: cluster 1 (MCG 01, 02, 04 and 05), cluster 2 (MCS 06, 07,

Table 1. The number of unique shared loci to each clam population and number of shared loci by the four clam population generated by PCR analysis using 6 oligonucleotides primers in the four Manila clam population, respectively

\begin{tabular}{|c|c|c|c|c|c|}
\hline Item & & $\begin{array}{l}\text { No. of } \\
\text { each cl }\end{array}$ & $\begin{array}{l}\text { loci to } \\
\text { pulation }\end{array}$ & & $\begin{array}{l}\text { No. of shared loci by the four } \\
\text { clam populations }\end{array}$ \\
\hline Primer $\backslash$ population & MCG & MCS & MCT & MCA & $\begin{array}{c}\text { Four populations } \\
\text { (5 individuals per population) }\end{array}$ \\
\hline OPA - 08 & 0 & 5 & 5 & 0 & 0 \\
\hline OPA - 09 & 10 & 15 & 0 & 0 & 0 \\
\hline OPA - 11 & 5 & 40 & 5 & 15 & 0 \\
\hline OPA - 16 & 0 & 40 & 60 & 25 & 0 \\
\hline OPA - 18 & 10 & 15 & 20 & 0 & 0 \\
\hline OPA - 20 & 0 & 0 & 15 & 10 & 0 \\
\hline Total no. & 25 & 115 & 105 & 50 & 0 \\
\hline $\begin{array}{l}\text { Average no. per } \\
\text { primer }\end{array}$ & 4.2 & 19.2 & 17.5 & 8.3 & 0 \\
\hline
\end{tabular}


J-M Yoon

Table 2. Multiple comparisons of average bandsharing values among four Manila clam populations were generated according to the bandsharing values and similarity matrix

\begin{tabular}{ccccc}
\hline \hline Population & MCG & MCS & MCT & MCA \\
\hline MCG & $0.402 \pm 0.115^{\mathrm{c}}$ & $0.366 \pm 0.170^{\mathrm{a}}$ & $0.432 \pm 0.168^{\mathrm{c}}$ & $0.381 \pm 0.175^{\mathrm{b}}$ \\
MCS & - & $0.637 \pm 0.227^{\mathrm{e}}$ & $0.446 \pm 0.093^{\mathrm{c}}$ & $0.387 \pm 0.160^{\mathrm{b}}$ \\
MCT & - & - & $0.632 \pm 0.229^{\mathrm{e}}$ & $0.417 \pm 0.191^{\mathrm{c}}$ \\
MCA & - & - & - & $0.435 \pm 0.188^{\mathrm{c}}$ \\
\hline
\end{tabular}

${ }^{\mathrm{a} \sim \mathrm{e}}$ Values with different superscript are significantly different, $P<0.05$.

Each value is a result of three different experiments.

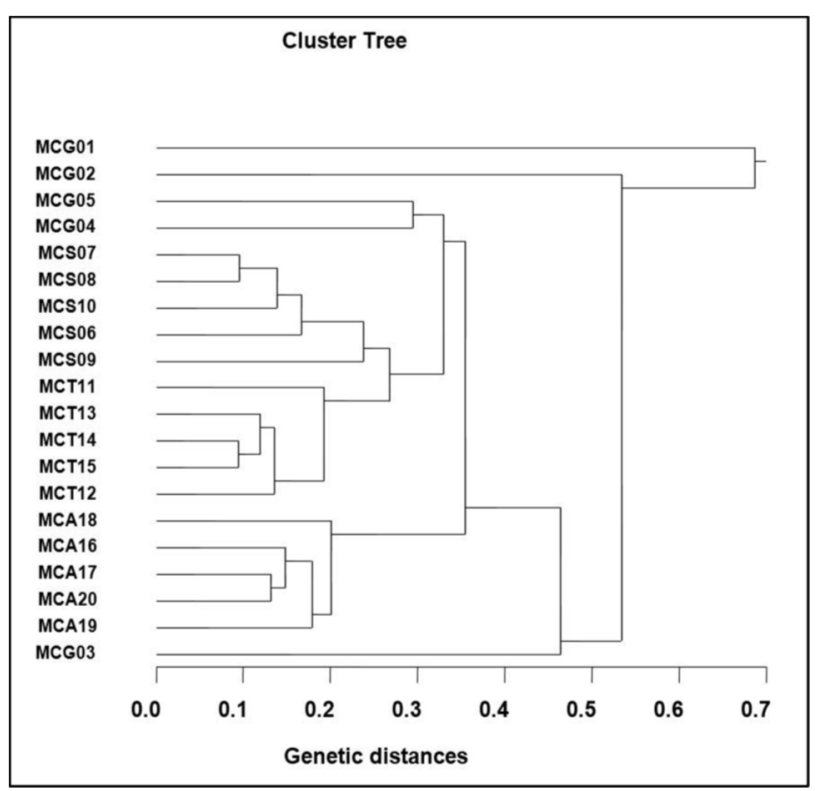

Fig. 1. Hierarchical dendrogram of genetic distances obtained from four Manila clam populations. The joining construction among different individuals of MCG clam population (MCG 01, 02, 04 and 05), MCS clam population (MCS 06, 07, 08, 09 and 10), MCT clam population (MCT 11, 12, 13, 14 and 15) and MCA clam population (MCA $16,17,18,19,20$ and MCG 03) generated according to the bandsharing values and similarity

08, 09 and 10), cluster 3 (MCT 11, 12, 13, 14 and 15) and cluster 4 (MCA 16, 17, 18, 19, 20 and MCG 03). Among the twenty clams, the shortest genetic distance that displayed significant molecular differences was between individuals 14 and 15 from the MCT population (genetic distance =
0.094), while the longest genetic distance among the twenty individuals that displayed significant molecular differences was between individuals MCG no. 01 and MCG no. 02 (genetic distance $=0.687)$. Relatively, individuals of Seocheon clam population were fairly closely related to that of MCT clam population, as shown in the hierarchical dendrogram of Euclidean genetic distances. The inter-population similarity indices and genetic distance values indicated that the Jamuna- Padma population pair of the Indian major carp (Catla catla) was genetically closer than the Halda-Jamuna and the Halda-Padma population pairs, which agreed with the geographical distances between them (Islam et al., 2005). They suggested that the RAPD technique could be used to discriminate between different river populations of major carp. In invertebrates, cluster analysis of the pairwise population matrix, generated from genetic data, showed that geographically close populations be inclined to cluster together in the blacklip abalone (Huang et al., 2000). As a whole, the population grouping of $R$. philippinarum is founded on morphological variations in shell type, shell color, shell length, shell width and feet length. The prospective of oligonucleotides amplified polymorphic DNAs to determine diagnostic markers for species, genus and population identification in crustacean has also been well recognized (Partis \& Wells, 1996; Tassanakajon et al., 1998; McCormack et al., 2000; Diaz-Jaimes \& Uribe-Alcocer, 
2003; Park et al., 2005; Song \& Yoon, 2013). PCR fragments revealed of in the present study may be valuable as a DNA marker the four regional populations to distinguish.

\section{ACKNOWLEDGEMENTS}

The author would like to thank the reviewers who assisted us with thorough and profound correction. Particular thanks go to our laboratory colleagues for their assistance in sample collection and their help with the technique of PCR analysis throughout this study. This work was partially supported by the Fisheries Science Institute of Kunsan National University in 2017.

\section{REFERENCES}

Cho TJ (2001) Sedimentological and hydromechanical characteristics of bed deposits for the cultivation of Manila clam, Ruditapes philippinarum in Gomso tidal flat. J Korean Fish Soc 34: 245-253.

Choi YS (2000) The relationship between environmental conditions and morphological characteristics of manila clam, Ruditapes philippinarum in the west coast of Korea, Bull Nat'l Fish Res Dev Inst Korea 58: 56-63.

Diaz-Jaimes P, Uribe-Alcocer M (2003) Allozyme and RAPD variation in the eastern Pacific yellowfin tuna (Thunnus albacares). Fish Bull 101: 769-777.

Huang BX, Peakall R, Hanna PJ (2000) Analysis of genetic structure of blacklip abalone (Haliotis rubra) populations using RAPD, minisatellite and microsatellite markers. Mar Biol 136: 207-216.

Islam MS, Ahmed ASI, Azam MS, Alam MS (2005) Genetic analysis of three river populations of Catla catla (Hamilton) using randomly amplified polymorphic DNAs markers. Asian-Aust J Anim Sci 18: 453-457.

Jeffreys AJ, Morton DB (1987) DNA fingerprints of dogs and cats. Anim Genet 18: 1-15.

Kang KH (2000) Growth comparison of short neck clams,
Tapes philippinarum between the two culturing areas. Korean J Malacol 16: 49-54.

Kwon JY (1999) Morphological variation and genetic relationship among populations of the shortnecked clam, Ruditapes philippinarum collected from different habitats. J Fish Sci Tech 2: 98-104.

Lee KY, Chung EY (2008) Ultrastructural studies of oogenesis and oocyte degeneration in female Ruditapes philippinarum (Bivalvia: Veneridae) from Gomso Bay, Korea. Dev Reprod 4: 41-49.

Lee YH (1996) Comparison of growth and survival rate in shortnecked clams, Ruditapes philippinarum from different seedling production areas. J Aquacult 9: 223-232.

McCormack GC, Powell R and Keegan B (2000) Comparative analysis of two populations of the brittle star Amphiura filiformis (Echinodermata: Ophiuroidae) with different life history strategies using RAPD markers. Mar Biotechnol 2: 100-106.

Muchmore ME, Moy GW, Swanson WJ, Vacquier VD (1998) Direct sequencing of genomic DNA for characterization of a satellite DNA in five species of Eastern Pacific abalone. Mol Mar Biol Biotechnol 7: 1-6.

Park SY, Park JS, Yoon JM (2005) Genetic differences and variations in slipper lobster (Ibacus ciliatus) and deep sea lobster (Puerulus sewelli) determined by RAPD analysis. Korean J Genet 25: 307-317.

Partis L, Wells RJ (1996) Identification of fish species using random amplified polymorphic DNA (RAPD). Mol Cell Probes 10: 435-441.

Robert R (1993) Growth, reproduction and gross biochemical composition of the Manila clam, Ruditapes philippinarum in the Bay of Arachon, France. Mar Biol 116: 291-299.

Shin YK (2000) Temperature and salinity tolerance of the manila clam, Ruditapes philippinarum. J Korean Fish Soc 33: 213-218.

Song YJ, Yoon JM (2013) Genetic differences of three Pollicipes mitella population identified by PCR analysis. 
Dev Reprod 17: 199-205.

Tassanakajon A, Pongsomboon S, Jarayabhand P, Klinbunga S, Boonsaeng V (1998) Genetic structure in wild populations of black tiger shrimp (Penaeus monodon) using randomly amplified polymorphic DNA analysis. J Mar Biotechnol 6: 249-254.

Yoon JM, Kim JY (2004) Genetic differences within and between populations of Korean catfish (S. asotus) and bullhead (P. fulvidraco) analysed by RAPD-PCR. AsianAust J Anim Sci 17: 1053-1061.

Yoke-Kqueen C, Radu S (2006) Random amplified polymorphic DNA analysis of genetically modified organisms. J Biotechnol 127: 161-166. 